\title{
The association between primary biliary cirrhosis and coeliac disease: a study of relative prevalences
}

\author{
J G C Kingham, D R Parker
}

\begin{abstract}
Background-Coexistent primary biliary cirrhosis (PBC) and coeliac disease has been recorded but the association has not been systematically studied.

Aims-To determine relative prevalences of PBC and coeliac disease in a defined population over a 12 year period.

Patients and methods-All patients with PBC or coeliac disease in a stable population of 250000 in South Wales were identified from a clinical register and laboratory records.

Results-Sixty seven patients with PBC and 143 patients with coeliac disease have been diagnosed and followed over a median of 86 (4-135) months; point prevalences in 1996 were 20 per 100000 for PBC and 54 per 100000 for coeliac disease. PBC in patients with coeliac disease was sought by investigating abnormal liver function tests. Ten (7\%) had persistent abnormalities and three had PBC. Coeliac disease in patients with PBC was sought by investigating malabsorption, haematinic deficiency, positive antigliadin antibody, or coeliac disease family history. Eleven patients underwent duodenal biopsy revealing one further coeliac disease case. Four patients (three women) have both conditions giving a point prevalence for patients with both conditions of $1.6 \mathrm{per}$ $100000(95 \%$ confidence limits 0.44 to 4.1 per 100 000). Prevalence of PBC in patients with coeliac disease was $3 \%$ and of coeliac disease in patients with PBC was $6 \%$.

Conclusion-A 12 year study of a stable 250000 population revealed a relative prevalence of PBC in $3 \%$ of 143 patients with coeliac disease and of coeliac disease in $6 \%$ of 67 patients with PBC. PBC and coeliac disease are therefore associated. Screening for PBC in patients with coeliac disease using antimitochondrial antibody testing and screening for coeliac disease in patients with PBC with antigliadin antibody testing or duodenal biopsy are recommended.

(Gut 1998;42:120-122)
\end{abstract}

Department of

Gastroenterology,

Singleton Hospital,

Swansea SA2 8QA, UK

J G C Kingham

D R Parker

Correspondence to:

Dr Kingham.

Accepted for publication 16 July 1997
Logan et al in $1978^{1}$ reported four patients from Edinburgh and Dublin with coexistent coeliac disease and primary biliary cirrhosis (PBC), questioning whether this was a significant association. They did not attempt to assess the frequency of each disease relative to the other nor did they systematically review their respective patient populations for these diseases. There have been several subsequent reports ${ }^{2-5}$ of these two diseases coexisting with over 20 cases described ${ }^{6}$ but there have been no formal attempts to ascertain relative prevalence rates.

\section{Methods}

Since 1984 we have kept a register of all patients with specifically defined gastroenterological and liver diseases from a well circumscribed and stable population in South Wales. The register has been maintained prospectively by coding at the time of diagnosis (discharge summary or letter to referring doctor) all inpatients, outpatients, and day cases passing through the department of gastroenterology.

The population is defined by the Unitary Authority of Swansea as follows: city of Swansea (postcodes SA1-SA9) population 226000 ; part of the surrounding rural area (postcodes SA14, 15, and 18) population 25000 . This population is $51.9 \%$ female, $48.1 \%$ male, and is predominantly of European ethnic origin (98.5\%). ONS figures for 1990-4 showed a $0.2 \%$ population growth with little migration or immigration.

Swansea is served by two district general hospitals with shared laboratory facilities and case notes giving ready access to records of histopathology, biochemistry, and serology results. We used the combined resources of our clinical register and computerised laboratory records to identify all cases of coeliac disease and all of PBC resident in this area. The clinical case notes were obtained after establishing any of the following:

Recorded clinical diagnosis of PBC or of coeliac disease.

- Histology record of partial or subtotal villous atrophy on small intestinal biopsy.

- Histology record of typical or probable PBC on liver biopsy.

- Positive antimitochondrial antibody of titre $1 / 40$ or greater.

After scrutiny of the case notes and subsequent re-evaluation and investigation we found 143 patients ( 105 women, 38 men) with coeliac disease and 67 patients ( 57 women, 10 men) with PBC who had been diagnosed and followed regularly over the period 1984-96. The diagnostic criteria for coeliac disease were partial or subtotal villous atrophy, with or without evidence of malabsorption, responsive to gluten withdrawal. The criteria for PBC were positive antimitochondrial antibody, cholestatic biochemistry, and liver biopsy consistent with 
Table 1 Liver function abnormalities in 35/143 patients with coeliac disease

\begin{tabular}{llll}
\hline $\begin{array}{l}\text { Pattern of liver function } \\
\text { transaminases }\end{array}$ & $\begin{array}{l}\text { No abnormal } \\
\text { at any time }\end{array}$ & $\begin{array}{l}\text { No persistently } \\
\text { abnormal }\end{array}$ & Diagnosis \\
\hline Bilirubin $\uparrow, \mathrm{AST} \uparrow, \mathrm{AP} \uparrow, \gamma-\mathrm{GT} \uparrow$ & 2 & 2 & $\begin{array}{l}\text { PBC } \\
\text { PBC }\end{array}$ \\
$\mathrm{AST} \uparrow, \mathrm{AP} \uparrow, \gamma-\mathrm{GT} \uparrow$ & 12 & 4 & $\begin{array}{l}\text { PBC } \\
\text { PBC }\end{array}$ \\
& 8 & NSRH \\
$\mathrm{AST} \uparrow$ & 10 & 2 & $\begin{array}{l}\text { MC } \\
\text { FNH }\end{array}$ \\
$\mathrm{AP} \uparrow, \gamma-\mathrm{GT} \uparrow$ & & 2 & $\begin{array}{l}\text { Fatty liver } \\
\text { Secondary } \\
\text { adenocarcinoma }\end{array}$ \\
& & & $\begin{array}{l}\text { Secondary } \\
\text { lymphoma }\end{array}$ \\
$\gamma-\mathrm{GT} \uparrow$ & 3 & 0 & \\
\hline AST, & & & \\
\hline
\end{tabular}

AST, aspartate aminotransferase; AP, alkaline phosphatase; $\gamma$-GT, $\gamma$-glutamyltransferase; PBC, primary biliary cirrhosis; NSRH, non-specific reactive hepatitis; MC, macronodular cirrhosis; $\mathrm{FNH}$, focal nodular hyperplasia.

PBC. Sixty seven were classified as having definite (56 patients) or probable (11 patients) PBC. $^{7}$ Confidence intervals were calculated using a Poisson distribution. ${ }^{8}$

\section{Results}

The catchment population from which these patients were drawn is approximately 250000 . In 1995, 136/143 patients with coeliac disease and 51/67 patients with PBC were alive. In that year all four patients with both conditions were still living, though in one coeliac disease had yet to be diagnosed; this came to light after investigation in 1996. Thus the point prevalence in this population in 1995 and 1996 of coeliac disease was 54 per 100000 and of PBC was 20 per 100000 . (The corresponding figures for women for 1996 are 77 per 100000 for coeliac disease and 34 per 100000 for PBC.)

Four patients were identified on clinical, histological, biochemical, and serological grounds as suffering from both conditions with a point prevalence of 1.6 per 100000 (95\% confidence limits 0.44 to 4.1 per 100000 ). In patients with coeliac disease evidence of PBC was sought by identifying abnormal liver function tests. Twenty four per cent $(35 / 143)$ had an abnormality of at least one liver function test at some point (table 1). Of these, most were transient and not specifically cholestatic. Ten patients had persistent abnormalities of liver function tests and were fully evaluated. Four had PBC, one macronodular cirrhosis, one focal nodular hyperplasia, one non-specific reactive hepatitis, one fatty liver, and two secondary cancer.

Of the 67 patients with PBC, one was simultaneously diagnosed as having coeliac disease; in two the diagnosis of coeliac disease was made first. In the remaining 64 patients with PBC evidence of possible coeliac disease was sought by features suggestive of malabsorption (in seven), a family history of coeliac disease (in one), the presence of antireticulin antibody (in one), or the finding of otherwise unexplained haematinic deficiency anaemia (in six). Eleven

Table 2 Case histories of the four patients with both PBC and coeliac disease

\begin{tabular}{|c|c|c|c|c|}
\hline Age & $\operatorname{Sex}$ & Symptoms and signs & Initial investigations & Subsequent investigations and outcome \\
\hline 51 & $\mathrm{~F}$ & $\begin{array}{l}\text { Diarrhoea, pruritus, weight } \\
\text { loss, pigmentation, } \\
\text { steatorrhoea }\end{array}$ & $\begin{array}{l}\mathrm{Hb} 11.3 \mathrm{~g} / \mathrm{dl} \text {; MCV } 76 \mathrm{fl} \text {; ferritin }<5 \mathrm{ng} / 1 \text {; folate } 1.6 \mathrm{ng} / \mathrm{ml} \text {; AP } \\
1813 \mathrm{U} / 1 \text {; bilirubin } 18 \mu \mathrm{mol} / 1 \text {; AST } 89 \mathrm{U} / 1 ; \gamma \text {-GT } 582 \mathrm{U} / 1 \text {; albumin } \\
35 \mathrm{~g} / 1 \text {; AMA } 1 / 1000 \text {; ANF } 1 / 40 \text {; liver biopsy: PBC, grade } 4 \\
\text { cirrhosis; duodenal biopsies: subtotal villous atrophy }\end{array}$ & $\begin{array}{l}\text { Gluten exclusion led to rapid resolution of } \\
\text { diarrhoea and weight gain, repeat duodenal } \\
\text { biopsy at 9/12: minimal partial villous } \\
\text { atrophy, liver disease progressed: liver } \\
\text { transplant at three years after initial } \\
\text { presentation, currently well }\end{array}$ \\
\hline 57 & $\mathrm{~F}$ & $\begin{array}{l}\text { Diarrhoea, abdominal pain, } \\
\text { weight loss, } \\
\text { hepatosplenomegaly }\end{array}$ & $\begin{array}{l}\mathrm{Hb} 8.8 \mathrm{~g} / \mathrm{dl} \text {; MCV } 76 \mathrm{fl} \text {; vitamin } \mathrm{B}_{12} 130 \mathrm{ng} / \mathrm{l} \text {; folate } 2.3 \mathrm{ng} / \mathrm{ml} \text {; } \\
\text { ferritin } 6 \mathrm{ng} / 1 \text {; faecal fat } 30 \mathrm{~g} / \text { day; AP } 36.5 \mathrm{KA} \text { units; AST } 164 \mathrm{U} / 1 \text {; } \\
\text { AMA } 1 / 2560 \text {; liver biopsy: PBC, grade } 3 \text { cirrhosis; duodenal } \\
\text { biopsies: subtotal villous atrophy }\end{array}$ & $\begin{array}{l}\text { Well for nine years then developed CRST } \\
\text { syndrome and hyperslenism, repeat } \\
\text { duodenal biopsies: partial villous atrophy, } \\
\text { repeat LFTs: AP } 540 \mathrm{U} / 1 \text {; AST } 47 \mathrm{U} / 1 \text {; } \\
\text { albumin } 31 \mathrm{~g} / 1 \text {, multiple transfusions } \\
\text { required for hypersplenism, died of } \\
\text { pneumonia } 15 \text { years after initial } \\
\text { presentation }\end{array}$ \\
\hline 32 & $\mathrm{~F}$ & $\begin{array}{l}\text { Pruritus, anorexia, weight } \\
\text { loss }\end{array}$ & 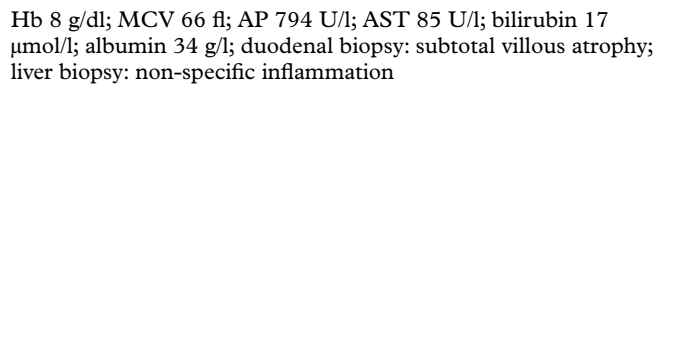 & $\begin{array}{l}\text { Gluten exclusion and haematinic } \\
\text { supplements resulted in weight gain, } \\
\text { pruritus persisted; LFTs remained } \\
\text { abnormal, started oral contraceptive: } \\
\text { developed jaundice; resolved on stopping, } \\
\text { LFTs remained abnormal; repeat duodenal } \\
\text { biopsy: good response to gluten exclusion, } \\
\text { AMA } 1 / 1024 \text {, review of previous liver } \\
\text { biopsy: PBC, four years after initial } \\
\text { presentation: xanthelasmata, spider naevi, } \\
\text { jaundice, hepatospenomegaly, started on } \\
\text { ursodeoxycholic acid: LFTs improved, } \\
\text { currently asymptomatic }\end{array}$ \\
\hline 51 & M & Osteoporosis & $\begin{array}{l}\text { AP } 1131 \mathrm{U} / 1 ; \text { AST } 77 \mathrm{U} / 1 ; \gamma-G T 904 \mathrm{U} / 1 \text {; liver biopsy: minimal } \\
\text { portal tract inflammation only }\end{array}$ & $\begin{array}{l}\text { No diagnosis at first, over next } 10 \text { years } \\
\text { developed pruritus, weight loss, } \\
\text { pigmentation, splenomegaly, LFTs } \\
\text { worsened, endoscopy revealed varices, } \\
\text { repeat liver biopsy: PBC, grade } 4 \text {, ERCP: } \\
\text { consistent with cirrhosis, AMA still } \\
\text { negative, iron deficiency anaemia } \\
\text { developed, low vitamin } \mathrm{B}_{12} \text {, duodenal } \\
\text { biopsies: subtotal villous atrophy, } \\
\text { antireticulin antibodies positive, gluten } \\
\text { exclusion resulted in improved well being, } \\
\text { repeat duodenal biopsy: mild partial villous } \\
\text { atrophy only, LFTs did not change after } \\
\text { gluten exclusion }\end{array}$ \\
\hline
\end{tabular}

$\mathrm{Hb}$, haemoglobin; MCV, mean cell colume; AP, alkaline phosphatase; AST, aspartate aminotrnasferase; $\gamma$-GT, $\gamma$-glutamyltransferase; AMA, antimitochondrial antibody; ANF, antinuclear factor; LFT, liver function test; PBC, primary biliary cirrhosis; ERCP, endoscopic retrograde cholangiopancreatography. 
patients underwent duodenal biopsy and one further case of coeliac disease came to light. Table 2 presents the case histories of the four patients with both PBC and coeliac disease.

\section{Discussion}

In a stable catchment population of approximately 250000 , the point prevalence in 1995 and 1996 of coeliac disease was 54 per 100000 and of PBC was 20 per 100000 . These figures are comparable with others published from the United Kingdom. The prevalence of coeliac disease in England and Wales based on Coeliac Society membership ${ }^{9}$ was estimated at 27 per 100000 whereas a higher figure of 61 per 100000 has been recorded in south east Scotland. ${ }^{10}$ Recent reports from north east England $^{11-13}$ on the epidemiology of PBC give prevalence figures increasing from 1.8 per 100000 in 1976 to 12.8 per 100000 in 1987 and 22.6 per 100000 in 1994 .

From our figures over a 12 year period with a median follow up of seven years, approximately $3 \%$ of patients with coeliac disease (4/143) might develop PBC while around 6\% of patients with PBC (4/67) might have underlying coeliac disease. There is no suggestion from these clinical and biochemical data, nor from those previously published, of a causative association between the two diseases nor that the activity of one influences the course of the other. The association presumably represents a shared susceptibility of biliary and small bowel epithelium to attack by autoimmune mechanisms.

This study probably underestimates the relative frequency of these two diseases as no attempt has been made to search for antimitochondrial antibodies in the entire group of coeliac patients nor has every patient with PBC been subjected to duodenal biopsy. Despite these deficiencies we believe prevalence figures of the order demonstrated in this study would be applicable to the rest of the United Kingdom and that the association proposed by Logan et $a l^{1}$ almost 20 years ago can be considered established. Given this association, screening for possible PBC in patients with coeliac disease using antimitochondrial antibody tests is recommended; similarly, screening for coeliac disease in patients with PBC could be readily performed with antigliadin antibody testing or duodenal biopsy when the presence of varices is being assessed.

We wish to thank Dr J Hywel Jones and Professor J G William for allowing us to study patients under their care and Dr Tim Peters and Miss Maria Lena Trivella of the University of Bristo Department of Social Medicine for statistical advice. This work has previously been published in abstract form (Hepatology 1996;24:533A)

1 Logan RFA, Ferguson A, Finlayson NDC, Weir DG. Primary biliary cirrhosis and coeliac disease, an association. Lancet 1978;i:230-3.

2 Iliffe GD, Owen DA. An association between primary biliary cirrhosis and jejunal villous atrophy resembling celiac disease. Dig Sci 1979;24:802-6.

3 Behr W, Barnert J. Adult celiac disease and primary biliary cirrhosis. Am $\mathcal{F}$ Gastroenterol 1986;81:796-9.

4 Olsson I, Kagevi I, Rydberg L. On the concurrence of primary biliary cirrhosis and intestinal villous atrophy. primary biliary cirrhosis and intes

5 Ginn P, Workman RD. Primary biliary cirrhosis and adult celiac disease. West $\mathcal{F}$ Med 1992;156:547-9.

6 Lohr M, Lotterer E, Hahn EG, Fleig WF. Primary biliary cirrhosis associated with coeliac disease. Eur $\mathcal{F}$ Gastroenterol Hepatol 1994;6:263-7.

7 Danielsson A, Boqvist L, Uddenfeldt P. Epidemiology of primary biliary cirrhosis in a defined rural population in the northern part of Sweden. Hepatology 1990;11:458-64.

8 Gardner MJ, Altman DG. Statistics with confidence - the confidence interval and statistical guidelines. London: BMJ Publishing Group, 1989

9 Swinson CM, Levi AJ. Is coeliac disease underdiagnosed? BMF 1980;281:1258-60.

10 Logan RFA, Rifkind EA, Busuttil A, Gilmour HM, Ferguson A. Prevalence and "incidence" of celiac disease in Edinburgh and the Lothian region of Scotland. Gastroenterology 1986;90:334-42.

11 Hamlyn AN, Macklon AF, James OFW. Primary biliary cirrhosis: geographical clustering and symptomatic onset cirrhosis: geographical clustering

12 Myszor M, James OFW. The epidemiology of primary biliary cirrhosis in North-East England: an increasingly common disease. QF Med 1990;276:377-85.

13 Metcalf JV, James OFW. Descriptive epidemiology of primary biliary cirrhosis (PBC): possible lessons for future transplantation requirements in Britain [abstract]. Gut 1996;38:A5 